\title{
PERAN POLA ASUH AUTORITATIF, EFIKASI DIRI, DAN PERILAKU PROSOSIAL TERHADAP KESEJAHTERAAN PSIKOLOGIS PADA REMAJA AKHIR DI PROGRAM STUDI PENDIDIKAN DOKTER GIGI FAKULTAS KEDOKTERAN UNIVERSITAS UDAYANA
}

\author{
Putu Novia Arya Putri, I Made Rustika \\ Program Studi Psikologi, Fakultas Kedokteran, Universitas Udayana \\ noviaaryaputri@gmail.com
}

\begin{abstract}
Abstrak
Kesejahteraan psikologis merupakan aspek penting yang menentukan kualitas hidup individu. Taraf kesejahteraan psikologis dapat ditentukan oleh faktor internal dan eksternal. Dua dari faktor internal adalah efikasi diri dan perilaku prososial, sedangkan salah satu faktor eksternal adalah pola asuh autoritatif. Tujuan penelitian ini adalah untuk mengetahui peran pola asuh autoritatif, efikasi diri, dan perilaku prososial terhadap kesejahteraan psikologis pada remaja akhir. Subjek pada penelitian ini adalah 129 remaja akhir di Program Studi Pendidikan Dokter Gigi Fakultas Kedokteran Universitas Udayana. Instrumen pada penelitian ini adalah skala kesejahteraan psikologis, skala pola asuh autoritatif, skala efikasi diri, dan skala perilaku prososial. Hasil analisis regresi berganda menunjukkan bahwa pola asuh autoritatif, efikasi diri, dan perilaku prososial secara bersama-sama berperan terhadap kesejahteraan psikologis. Sumbangan efektif pola asuh autoritatif, efikasi diri, dan perilaku prososial terhadap kesejahteraan psikologis sebesar 66,6\%. Koefisien beta terstandarisasi efikasi diri sebesar 0,669 ( $<<0,05)$, menunjukkan bahwa efikasi diri berperan secara signifikan terhadap kesejahteraan psikologis. Koefisien beta terstandarisasi perilaku prososial sebesar $0,178(\mathrm{p}<0,05)$, menunjukkan bahwa perilaku prososial berperan secara signifikan terhadap kesejahteraan psikologis. Koefisien beta terstandarisasi pola asuh autoritatif sebesar 0,104 ( $>0,05)$, menunjukkan bahwa pola asuh autoritatif tidak berperan secara signifikan terhadap kesejahteraan psikologis.
\end{abstract}

Kata Kunci: kesejahteraan psikologis, pola asuh autoritatif, efikasi diri, perilaku prososial

\begin{abstract}
Psychological well-being is an important aspect that determines the individual quality of life. The level of psychological well-being can be determined by internal and external factors. Both of the internal factors are selfefficacy and prosocial behavior. Meanwhile, one of the external factors is authoritative parenting style. The purpose of this study was to identify the roles of authoritative parenting style, self-efficacy, and prosocial behavior toward psychological well-being of late adolescents. The subjects in this study were 129 of late adolescents at School of Dentistry, Faculty of Medicine, Udayana University. The instruments in this study were psychological well-being scale, authoritative parenting style scale, self-efficacy scale, and prosocial behavior scale. The results of multiple regression analysis indicated that simultaneously, authoritative parenting style, self-efficacy, and prosocial behavior contributed toward psychological well-being. The effective contribution of authoritative parenting style, self-efficacy, and prosocial behavior toward psychological well-being was $66,6 \%$. Self-efficacy standardized beta coefficient was $0,669(\mathrm{p}<0,05)$, indicated that significantly, self-efficacy contributed toward psychological well-being. Prosocial behavior standardized beta coefficient was $0,178(\mathrm{p}<0,05)$, indicated that significantly, prosocial behavior contributed toward psychological well-being. Authoritative parenting style standardized beta coefficient was $0,104(\mathrm{p}>0,05)$, indicated that significantly, authoritative parenting style did not contribute toward psychological well-being.
\end{abstract}

Keywords: psychological well-being, authoritative parenting style, self-efficacy, prosocial behavior 


\section{LATAR BELAKANG}

Ryff (1989) mendefinisikan kesejahteraan psikologis sebagai kondisi mental yang dianggap sehat dan berfungsi maksimal. Kesejahteraan psikologis menjadi faktor penting dalam menentukan kualitas hidup individu. Kondisi mental yang sehat mengarahkan individu untuk berusaha mencapai suatu keseimbangan dalam hidup dengan menerima kualitas positif dan negatif diri, menyadari potensi yang dimiliki, mampu menyesuaikan diri dengan kondisi yang sulit, serta mampu memberikan kontribusi kepada orang lain dan lingkungan sekitar. Kesejahteraan psikologis mengarah pada kebahagiaan dan pencapaian penuh atas potensi psikologis sebagai hasil dari pengalaman hidup, sehingga mampu berfungsi secara optimal. Pencapaian kesejahteraan psikologis berkaitan dengan adanya hasrat untuk selalu bertumbuh dan berkembang menjadi pribadi yang produktif melalui pedoman dan kebermaknaan dalam hidup. Kesejahteraan psikologis memiliki nilai yang tinggi dalam kehidupan, sehingga setiap individu akan berupaya dengan berbagai cara untuk mencapai kesejahteraan psikologis. Ryff dan Keyes (1995) memberikan gambaran tentang kesejahteraan psikologis sebagai model multidimensi yang menekankan pada sejauh mana individu dapat bertanggung jawab terhadap hidupnya. Kesejahteraan psikologis dapat ditandai dengan diperolehnya kebahagiaan, kepuasan hidup, dan tidak adanya tanda-tanda depresi.

Menurut Ryff (1989) ada enam dimensi dari kesejahteraan psikologis, yaitu penerimaan diri, perkembangan pribadi, tujuan hidup, hubungan yang positif dengan orang lain, penguasaan lingkungan, dan kemandirian. Pada hakikatnya untuk mampu berfungsi secara optimal dalam menjalani kehidupan, individu harus memiliki kesejahteraan psikologis yang tinggi. Individu dengan kesejahteraan psikologis yang tinggi, memiliki sikap yang positif terhadap diri, mampu menjalin hubungan yang berkualitas dengan orang lain, memiliki kemandirian, adanya hasrat untuk menjadi pribadi yang selalu berkembang, serta memiliki tujuan dan makna hidup. Tidak semua individu memiliki kesejahteraan psikologis yang tinggi, ada beberapa individu yang hanya mampu berfungsi secara minimal dalam menjalani kehidupan. Individu dengan kesejahteraan psikologis yang rendah, memiliki ketidakpuasan dalam diri, merasa terisolasi dari lingkungan sosial, memiliki ketergantungan yang berlebihan dengan orang lain, adanya ketidakpekaan terhadap lingkungan, mengalami stagnasi dalam hidup, serta merasa hidup tidak bermakna (Ryff, 1989).

Menurut Ryff (1989) gambaran tentang karakteristik individu yang memiliki kesejahteraan psikologis mengacu pada pandangan Maslow tentang aktualisasi diri, pandangan Rogers tentang pemenuhan diri, pandangan Jung tentang individuasi, dan pandangan Erikson tentang penyelesaian krisis psikososial dalam setiap tahapan perkembangan. Maslow (dalam Feist \& Feist, 2013) menyatakan bahwa aktualisasi diri adalah kebutuhan yang mencakup pemenuhan diri, sadar akan semua potensi yang dimiliki, dan keinginan untuk menjadi kreatif. Individu yang mencapai aktualisasi diri dapat menerima diri apa adanya dengan kelemahan dan kelebihan yang dimiliki, menerima kekurangan orang lain dan tidak merasa terancam dengan kelebihan orang lain, serta tidak menuntut adanya kesempuraan karena setiap hal didunia ini tidak ada yang sempurna. Rogers (dalam Feist \& Feist, 2013) menyatakan bahwa individu memiliki kebutuhan untuk meningkatkan diri yang diekspresikan dalam bentuk rasa ingin tahu, kebahagiaan, eksplorasi diri, pertemanan, dan kepercayaan diri untuk meraih perkembangan psikologis. Ketika individu terlibat dalam hubungan yang dilandasi kejujuran, empati, dan penerimaan positif yang tidak bersyarat, maka individu akan bergerak menuju perubahan personal yang konstruktif dan memiliki kecenderungan alamiah untuk menuju pemenuhan diri. Jung (dalam Feist \& Feist, 2013) menyatakan bahwa individuasi atau realisasi diri merupakan proses untuk menjadi individu secara utuh yang berarti memiliki seluruh komponen psikologis yang berfungsi dalam satu kesatuan. Individuasi menjadi tahapan yang sulit dan hanya bisa dicapai oleh individu yang telah mampu mengasimilasi kesadaran dengan keseluruhan kepribadian, mengizinkan ketidaksadaran diri menjadi inti dari kepribadian, serta mampu menempatkan diri di dunia internal dan eksternal. Erikson (dalam Feist \& Feist, 2013) menyatakan bahwa dalam siklus kehidupan, individu memiliki delapan tahapan perkembangan psikososial dimana pada tiap tahap terjadi krisis psikososial. Setiap individu diharapkan mampu menyelesaikan krisis psikososial pada tiap tahap. Keberhasilan menyelesaikan krisis psikososial akan menghasilkan kekuatan dasar dan memungkinkan individu untuk bergerak ke tahap selanjutnya.

Menurut Erikson (dalam Feist \& Feist, 2013) periode masa remaja merupakan tahapan perkembangan yang paling krusial, karena pada tahapan ini remaja akan mengahadapi krisis antara identitas diri dengan kebingungan identitas. Pencarian akan identitas diri akan mencapai puncaknya selama remaja, karena pada periode ini remaja akan berusaha untuk mencari tahu siapa dirinya. Remaja akan mencari berbagai peran dan menarik beragam gambaran diri untuk menemukan identitas diri. Kebingungan identitas menjadi bagian yang dibutuhkan dalam pencarian identitas, namun kebingungan identitas yang berlebihan dapat mengakibatkan penyesuaian patologis dalam bentuk kemunduran ke tahapan perkembangan sebelumnya. Krisis antara identitas diri dan kebingungan identitas harus mampu terselesaikan sebelum individu memasuki masa dewasa muda yang ditandai dengan adanya identitas diri yang tetap.

Santrock (2007b) mendefinisikan masa remaja sebagai periode transisi perkembangan antara masa kanakkanak dengan masa dewasa yang melibatkan perubahanperubahan biologis, kognitif, dan sosioemosional. Tugas 
pokok remaja adalah mempersiapkan diri memasuki masa dewasa. Havighurst (dalam Hurlock, 1980) menyatakan bahwa tugas perkembangan remaja meliputi kemampuan dalam mencapai hubungan baru yang lebih matang dengan teman sebaya baik pria maupun wanita, mencapai peran sosial sebagai pria atau wanita, mencapai kemandirian emosional, mempersiapkan karir ekonomi, serta menerima keadaan fisik dan menggunakan tubuh secara efektif.

Santrock (2007b) menyatakan bahwa masa remaja dibedakan menjadi dua periode, yaitu periode awal dan periode akhir. Rentang usia remaja dimulai sekitar usia 10 hingga 13 tahun dan berakhir pada sekitar usia 18 hingga 22 tahun. Masa remaja awal kurang lebih berlangsung di masa sekolah menengah pertama dan sekolah menengah akhir. Masa remaja akhir kurang lebih terjadi pada pertengahan dasawarsa yang kedua dalam kehidupan. Minat karir, pacaran, dan eksplorasi identitas sering kali lebih menonjol di masa remaja akhir dibandingkan di masa remaja awal. Hurlock (1980) menyatakan bahwa masa remaja akhir menjadi ambang masa dewasa, sehingga remaja mulai memusatkan diri pada perilaku yang dihubungkan dengan status kedewasaan. Menurut Sarwono (2013) penyesuaian diri menuju kedewasaan yang terjadi pada masa remaja akhir, ditandai dengan adanya minat yang kuat terhadap fungsi-fungsi intelek, keinginan ego untuk bersatu dengan orang-orang lain dan mengalami pengalaman baru, identitas seksual yang menetap, keseimbangan antara kepentingan diri sendiri dengan orang lain, dan dapat memisahkan hal-hal yang bersifat pribadi dengan hal-hal yang bersifat umum.

Menurut Hurlock (1980) masa remaja akhir menjadi periode yang krusial secara psikologis, karena memungkinkan adanya kegagalan dalam melaksanakan peralihan ke arah kematangan sebagai tugas perkembangan yang terpenting pada masa remaja akhir. Kondisi psikologis yang tidak matang disebabkan oleh kegagalan melakukan peralihan ke perilaku yang lebih matang, seperti perilaku sosial, seksual dan moral, serta ketidakmatangan dalam hubungan keluarga. Bila ketidakmatangan tampak jelas, maka dapat menimbulkan penolakan diri yang merusak penyesuaian pribadi dan sosial. Remaja akhir yang mengetahui bahwa sikap dan perilakunya dianggap tidak matang oleh kelompok sosial dan menyadari bahwa orang lain memandangnya tidak mampu menjalankan peran dewasa yang baik, akan mengembangkan konsep rendah diri. Meskipun remaja tidak meletakkan standar-standar yang sangat tinggi bagi dirinya sendiri, namun akan muncul adanya kesenjangan antara apa yang diinginkan dan apa pandangannya tentang diri sendiri. Apabila kesenjangan ini kecil, maka remaja akan mengalami sedikit ketidakpuasan. Apabila kesenjangan ini lebar, maka remaja cenderung menganggap dirinya tidak berharga dan merenung atau mencoba bunuh diri. Santrock (2007c) menyatakan bahwa ragam masalah yang dihadapi remaja memiliki cakupan yang luas dan bervariasi apabila dilihat dari tingkat keparahan, tingkat perkembangan, jenis kelamin, dan sosioekonomi. Empat masalah yang memengaruhi sebagian besar remaja adalah masalah penyalahgunaan obat, masalah kenakalan remaja, masalah seksual, dan masalah yang berkaitan dengan sekolah. Kondisi ketidakmatangan ini terjadi secara nyata di masyarakat.

Aparat Polres Bogor Kota Jawa Barat menangkap 18 remaja yang melakukan pesta narkoba di sejumlah tempat berbeda (Hasan, 2013). Putri adalah remaja yang menjadi terdakwa kasus narkoba. Putri telah mengkonsumsi rokok, alkohol, dan narkoba sejak usia 14 tahun hingga usia 20 tahun, sehingga Putri berada pada tahap ketergantungan berat (Liputan 6, 2011). Sarwono (2013) menyatakan bahwa sifat narkoba dan alkohol dapat menimbulkan ketergantungan atau kecanduan bagi pemakainya, sehingga pada suatu saat tidak mampu melepaskan diri lagi. Penyalahgunaan narkoba dan alkohol dilakukan oleh para remaja yang memiliki jiwa yang tidak stabil dan adanya masalah dengan kesehatan mental. Ryff (1989) menyatakan bahwa kesejahteraan psikologis didefinisikan sebagai kondisi mental yang sehat dan berfungsi maksimal, sehingga ketergantungan pada narkoba dan alkohol menunjukkan individu dengan taraf kesejahteraan psikologis rendah. Menurut Santrock (2007c) salah satu alasan penyalahgunaan narkoba dan alkohol pada remaja adalah untuk melarikan diri dari realitas dunia. Hal ini dapat disebabkan oleh kekecewaan dan ketidakpuasan dalam hidup, sehingga mengarahkan pada tidak adanya perasaan atas hidup yang bermakna. Individu dengan taraf kesejahteraan psikologis rendah ditandai dengan tidak adanya makna hidup (Ryff, 1989).

Ada beberapa individu yang mampu menjalani masa remaja dengan baik dan mampu mencapai kesuksesan di usia muda. Agus adalah remaja berusia 21 tahun yang telah menjadi penggerak sekolah rakyat di Dusun Ranca Belut, Desa Tanjung Wangi, Cicalengka, Jawa Barat. Agus mulai merintis sekolah rakyat sejak berusia 15 tahun dengan visi, yaitu memberikan kesempatan pendidikan bagi anak-anak melalui sekolah rakyat (Liputan 6, 2015). Hal yang serupa dilakukan oleh Christy Zakarias, seorang remaja yang mengisi waktu luangnya dengan mengajar Bahasa Inggris dan menggalang teman-temannya untuk ikut mengajar anak-anak secara gratis. Christy memiliki visi yaitu meningkatkan kemampuan Bahasa Inggris anak-anak dengan cara membentuk komunitas Bahasa Inggris untuk anak-anak. Pada tahun 2013, Christy merupakan warga Indonesia pertama yang mendapatkan penghargaan Diana Award, sebagai penghargaan kepada anak-anak muda yang menginspirasi. (Qodar, 2015). Visi yang mendasari remaja dalam memperoleh suatu pencapaian, berkaitan dengan tujuan hidup yang menunjukkan adanya pedoman dan keterarahan dalam hidup. Kesuksesan yang diraih di usai muda mengarahkan remaja memiliki 
perasaan positif berupa rasa bahagia, bangga, dan harga diri, sehingga dapat memunculkan penilaian diri yang positif. Penilaian diri yang positif dibutuhkan dalam penerimaan diri atas kualitas positif dan negatif diri. Individu dengan taraf kesejahteraan psikologis tinggi ditandai dengan adanya tujuan hidup dan penerimaan diri (Ryff, 1989).

Mahasiswa kedokteran gigi yang tergolong remaja akhir memiliki kecenderungan mengalami stres dalam menjalani proses pembelajaran, karena adanya berbagai tuntuan perkuliahan yang harus dihadapi (Polimpung, 2012). Menurut Polychronopoulou dan Divaris (2009) proses pendidikan di kedokteran gigi merupakan salah satu proses pembelajaran yang memiliki banyak tantangan, tuntutan, dan tingkat stres yang tinggi. Mahasiswa kedokteran gigi dituntut untuk memenuhi kompetensi, seperti kompetensi akademik dan klinik, serta kemampuan interpersonal dalam menjalin hubungan dengan orang lain. Penelitian Alzahem, dkk, (2011) menunjukkan bahwa sumber stres pada mahasiswa kedokteran gigi berkaitan dengan ujian, dental supervisor, serta kebutuhan dan syarat klinik. Cripss \& Zyromski (2009) menyatakan bahwa stres psikologis dapat menyebabkan pikiran dan emosi negatif yang akan berdampak pada kesejahteraan psikologis remaja.

Berdasarkan paparan tersebut timbul pertanyaan dari peneliti, mengapa ada remaja akhir yang memiliki kesejahteraan psikologis yang tinggi dan mengapa ada remaja akhir yang memiliki kesejahteraan psikologis yang rendah ?

Ryff (2014) menyatakan bahwa kesejahteraan psikologis berkaitan dengan pengalaman yang diperoleh individu di lingkungan keluarga. Keluarga merupakan pendidikan informal bagi anak dalam belajar berbagai hal, seperti interaksi, nilai, moral, sikap, dan perilaku. Aktivitas keluarga memengaruhi kesejahteraan psikologis pada remaja, namun adanya variasi dalam aktivitas keluarga dapat disebabkan oleh perbedaan budaya pada setiap daerah (Maynard \& Harding, 2010). Pengalaman pribadi yang berkembang dari hubungan orangtua dan remaja menjadi sumber bagi remaja dalam melakukan evaluasi diri dan interaksi dengan orang lain. Hubungan antara orangtua dan remaja akan memengaruhi sikap remaja terhadap diri sendiri dan kualitas hubungan dengan teman sebaya (Gecas; Wilkinson dalam Cripss \& Zyromski, 2009). Penelitian Gecas (dalam Cripps \& Zyromski, 2009) menunjukkan bahwa dukungan orangtua dapat meningkatkan evalusi diri yang mengacu pada kepuasan diri dan kebahagiaan remaja.

Menurut Baumrind (2005) ada empat tipe pola asuh orangtua, yaitu pola asuh autoritatian, permisif, tidak peduli, dan autoritatif. Baumrind (1966) menyatakan bahwa orangtua yang menerapkan pola asuh autoritatif akan berupaya untuk mengarahkan aktivitas anak secara rasional, mendorong anak untuk berani berpendapat melalui dialog secara verbal, mendengarkan pendapat anak, bersedia berbagi dengan anak terkait alasan menetapkan suatu aturan, dan menerima apabila anak menolak untuk menyesuaikan dengan aturan yang diterapkan. Orangtua dengan pola asuh autoritatif akan menetapkan ketegasan terkait kualitas anak dan menetapkan standar bagi perilaku anak dimasa depan. Orangtua juga menekankan pada keseimbangan antara kesenangan dan tugas, kebebasan dan tanggungjawab, serta otonomi dan disiplin. Pola asuh autoritatif berhubungan dengan hasil perkembangan yang positif, evaluasi diri yang positif, tingkat harga diri yang tinggi, penyesuaian diri, dan motivasi instrinsik untuk belajar yang tinggi. Penelitian Buri, Kirchner, dan Walsh (dalam Cripps \& Zyromski, 2009) menunjukkan bahwa adanya hubungan yang signifikan antara pola asuh autoritatif yang diterapkan orangtua dengan harga diri remaja. Individu dengan harga diri yang tinggi diprediksi memiliki taraf kesejahteraan psikologis tinggi (Ryff, 2014).

Carr (2004) menyatakan bahwa kesejahteraan psikologis adalah pencapaian penuh potensi psikologis individu. Kesejahteraan psikologis lebih menekankan pada kondisi optimis dibandingkan kondisi pesimis. Individu yang pesimis berkaitan dengan depresi, ketakutan, dan kecemasan dalam menghadapi situasi dengan ketidakpastian. Individu yang optimis akan membantu diri dengan menggunakan kemampuan yang dimiliki dalam mempersiapkan strategi untuk mengelola situasi dengan berbagai tekanan. Kemampuan dalam mengelola berbagai peluang yang ada pada setiap tekanan akan terkait dengan perubahan yang positif dalam kesejahteraan fisik, kesejahteraan psikologis, dan peningkatan kemampuan diri. Individu yang optimis akan memiliki ketangguhan dan keyakinan dalam diri atas kemampuan yang dimiliki, ketika menghadapi situasi dengan ketidakpastian. Penelitian Archana, Kumar, dan Singh (2014) menunjukkan bahwa kesejahteraan psikologis berhubungan dengan perasaan gembira, kebahagiaan, emosi positif, harapan, optimis, efikasi diri, dan resiliensi.

Bandura (1997) menyatakan bahwa efikasi diri adalah keyakinan terhadap kemampuan diri dalam mengatur dan melaksanakan tugas yang bertujuan untuk menghasilkan suatu pencapaian. Efikasi diri berfokus pada bagaimana individu percaya bahwa dirinya mampu melakukan sesuatu, ketika berada dalam berbagai keadaan. Individu dengan taraf efikasi diri tinggi ditandai dengan adanya keyakinan yang konsisten dan kuat dalam menyelesaikan berbagai tugas menantang, karena merasa dapat mengaplikasikan kemampuan diri pada tugas yang akan dihadapi. Penelitian Flouri dan Buchanan (dalam Cripps \& Zyromski, 2009) menunjukkan bahwa efikasi diri berhubungan positif dengan konsep kebahagiaan dalam kesejahteraan psikologis.

Sarwono (2013) menyatakan bahwa masa remaja akhir ditandai dengan adanya keinginan untuk bersama dengan orang lain. Menurut Santrock (2007c) remaja memiliki kebutuhan yang kuat untuk disukai dan diterima oleh teman 
sebaya atau kelompok. Penerimaan teman sebaya berkaitan dengan adanya kompetensi sosial yang dapat dikembangkan melalui perilaku prososial. William (dalam Zainuddin dan Hidayat, 2008) menyatakan bahwa perilaku prososial berkaitan dengan perilaku yang memiliki intensi untuk mengubah keadaan fisik atau psikologis orang lain yang kurang baik menjadi lebih baik, dalam arti bentuk material maupun psikologis. Dalam hal ini perilaku prososial bertujuan untuk membantu meningkatkan well-being.

Santrock (2007a) menyatakan bahwa perilaku prososial adalah adanya kepedulian terhadap keadaan dan hak orang lain, perhatian dan empati terhadap orang lain, serta berbuat sesuatu yang memberikan manfaat bagi orang lain. Menurut Eisenberg dan Mussen (1989) karakteristik perilaku prososial adalah adanya kejujuran, kesediaan dalam berbagi, bekerjasama, dan menolong orang lain. Individu yang bahagia ditandai dengan adanya kemampuan bekerjasama, prososial, murah hati, dan fokus pada kebutuhan orang lain (Kasser \& Ryan, dalam Verdugo, dkk, 2011). Individu dengan emosi positif memiliki pikiran prososial dan perilaku membantu orang lain (Schroeder, dkk, dalam Verdugo, dkk, 2011).

Berdasarkan pemaparan yang telah disampaikan, peneliti tertarik untuk mengadakan sebuah penelitian mengenai "Peranan Pola Asuh Autoritatif, Efikasi Diri, dan Perilaku Prososial dengan Kesejahteraan Psikologis Pada Remaja Akhir di Program Studi Pendidikan Dokter Gigi Fakultas Kedokteran Universitas Udayana”.

\section{METODE}

\section{Variabel dan definisi operasional}

Variabel bebas dalam penelitian ini adalah pola asuh autoritatif, efikasi diri, dan perilaku prososial, sedangkan variabel tergantung dalam penelitian ini adalah kesejahteraan psikologis.

Definisi operasional kesejahteraan psikologis adalah pencapaian tujuan hidup yang dilandasi oleh evaluasi kompetensi diri secara cermat, hasrat untuk selalu mengembangkan diri, kemandirian, mengelola berbagai ancaman dari lingkungan menjadi daya dorong untuk kemajuan, serta mampu menjalin hubungan positif dengan orang lain. Variabel kesejahteraan psikologis diukur dengan menggunakan skala yang disusun oleh peneliti berdasarkan dimensi yang dikemukakan oleh Ryff (1989), yaitu penerimaan diri, hubungan positif dengan orang lain, kemandirian, penguasaan lingkungan, tujuan hidup, dan perkembangan pribadi.

Definisi operasional pola asuh autoritatif adalah tipe pengasuhan orangtua yang memiliki keseimbangan antara responsiveness dan demaningness, dimana orangtua menunjukkan kehangatan, dukungan otonomi, dan komunikasi dua arah, namun tetap melakukan kontrol dan mengawasi aktivitas anak. Variabel pola asuh autoritatif diukur dengan menggunakan skala yang disusun oleh Rustika (2014), skala ini telah melalui uji reliabilitas dengan menggunakan alpha cronbach yang menunjukkan bahwa skala memiliki koefisien reliabilitas sebesar 0,901 dan telah melalui uji validitas dengan menggunakan confirmatory factor analysis yang menunjukkan bahwa skala memiliki unidimensional yang dapat diterima sehingga dinyatakan valid. Pengukuran pola asuh autoritatif didasari oleh empat dimensi, yaitu kehangatan interaksi orangtua dengan anak, tegas dalam mengarahkan perilaku anak, tanggap memenuhi kebutuhan kasih sayang anak, dan menetapkan perilaku yang diharapkan.

Definisi operasional efikasi diri adalah keyakinan atas kemampuan diri untuk berfungsi secara optimal dalam suatu pencapaian yang dilandasi dengan adanya keyakinan yang konsisten dan kuat dalam menyelesaikan berbagai tugas menantang meskipun mengalami berbagai hambatan, karena yakin akan mampu mengaplikasikan kompetensi diri pada bidang tugas yang akan dihadapi. Variabel efikasi diri diukur menggunakan skala yang dimodifikasi dari skala yang disusun oleh Rustika (2014). Pengukuran efikasi diri didasari oleh tiga dimensi yang dikemukakan oleh Bandura (1997), yaitu tingkat kesulitan tugas (Level), kemantapan keyakinan (Strength), luas bidang perilaku (Generality).

Definisi operasional perilaku prososial adalah perilaku sosial dengan tujuan untuk memberikan konsekuensi positif bagi orang lain yang dilakukan secara sukarela atau tanpa pamrih yang didasari dengan adanya kerjasama, perilaku memberi, membantu orang lain, dan mendahulukan kepentingan orang lain daripada diri sendiri. Variabel perilaku prososial diukur menggunakan skala yang disusun oleh peneliti berdasarkan dimensi yang dikemukakan oleh Wrightsman dan Deaux (1981), yaitu Cooperating, Helping, Donating, dan Altruism.

\section{Responden}

Populasi dalam penelitian ini adalah remaja akhir di Program Studi Pendidikan Dokter Gigi Fakultas Kedokteran Universitas Udayana. Karakteristik subjek dalam penelitian ini adalah subjek merupakan remaja akhir berusia 18-21 tahun yang menjadi mahasiswa Program Studi Pendidikan Dokter Gigi Fakultas Kedokteran Universitas Udayana.

Teknik pengambilan sampel yang dilakukan pada penelitian ini adalah dengan menggunakan salah satu teknik nonprobability sampling yaitu sampling jenuh. Sampling jenuh adalah teknik penentuan sampel bila semua anggota populasi digunakan sebagai sampel (Sugiyono, 2012). Jumlah sampel dalam penelitian ini adalah 129 orang. 


\section{Tempat penelitian}

Pengambilan data dilakukan di Program Studi Pendidikan Dokter Gigi Fakultas Kedokteran Universitas Udayana pada tanggal 21 Oktober 2015 di semester I, pada tanggal 22 Oktober 2015 di semester III, dan pada tanggal 23 Oktober 2015 di semester V.

\section{Alat ukur}

Peneliti menggunakan empat skala dalam penelitian ini, yaitu skala kesejahteraan psikologis, skala pola asuh autoritatif, skala efikasi diri, dan skala perilaku prososial. Pernyataan dalam skala penelitian dikelompokkan menjadi item favorable dan unfavorable. Skala dalam penelitian ini merupakan skala Likert yang terdiri dari empat alternatif jawaban pada masing-masing item, yaitu: Sangat Tidak Sesuai (STS), Tidak Sesuai (TS), Sesuai (S), dan Sangat Sesuai (SS). Skala kesejahteraan psikologis terdiri dari 35 item, skala pola asuh autoritatif terdiri dari 24 item, skala efikasi diri terdiri dari 30 item, dan skala perilaku prososial terdiri dari 29 item.

Skala pengukuran kesejahteraan psikologis dalam penelitian ini menggunakan skala yang disusun oleh peneliti yang telah diuji validitas dan reliabilitasnya. Hasil uji validitas pada skala kesejahteraan psikologis menunjukkan bahwa koefisien korelasi item total berkisar antara 0,381 - 0,659. Hasil uji reliabilitas pada skala kesejahteraan psikologis menunjukkan bahwa koefisien reliabilitas sebesar 0,927. Alpha $(\alpha)$ sebesar 0,927 menggambarkan bahwa skala ini mampu mencerminkan $92,7 \%$ variasi yang terjadi pada skor murni subjek, sehingga mampu mengukur atribut kesejahteraan psikologis.

Skala pengukuran pola asuh autoritatif dalam penelitian ini menggunakan skala yang disusun oleh Rustika (2014), skala ini telah melalui uji reliabilitas dengan menggunakan alpha cronbach yang menunjukkan bahwa skala memiliki koefisien reliabilitas sebesar 0,901 dan telah melalui uji validitas dengan menggunakan confirmatory factor analysis yang menunjukkan bahwa skala memiliki unidimensional yang dapat diterima sehingga dinyatakan valid.

Skala pengukuran efikasi diri dalam penelitian ini menggunakan skala yang dimodifikasi dari skala yang disusun oleh Rustika (2014). Hasil uji validitas pada skala efikasi diri menunjukkan bahwa koefisien korelasi item total berkisar antara 0,325 - 0,585. Hasil uji reliabilitas pada skala efikasi diri menunjukkan bahwa koefisien reliabilitas sebesar 0,900. Alpha $(\alpha)$ sebesar 0,900 menggambarkan bahwa skala ini mampu mencerminkan 90,0\% variasi yang terjadi pada skor murni subjek, sehingga mampu mengukur atribut efikasi diri.

Skala pengukuran perilaku prososial dalam penelitian ini menggunakan skala yang disusun oleh peneliti yang telah diuji validitas dan reliabilitasnya. Hasil uji validitas pada skala perilaku prososial menunjukkan bahwa koefisien korelasi item total berkisar antara $0,332-0,683$. Hasil uji reliabilitas skala perilaku prososial menunjukkan bahwa koefisien reliabilitas sebesar 0,901. Alpha $(\alpha)$ sebesar 0,901 menggambarkan bahwa skala ini mampu mencerminkan 90,1\% variasi yang terjadi pada skor murni subjek, sehingga mampu mengukur atribut perilaku prososial.

\section{Teknik analisis data}

Uji hipotesis dalam penelitian ini menggunakan teknik regresi berganda. Sugiyono (2014) menyatakan bahwa analisis regresi berganda merupakan analisis statistik parametrik, sehingga mensyaratkan data terdistribusi secara normal. Analisis ini dapat mengukur jenis data interval dan rasio. Analisis regresi berganda digunakan untuk mengetahui peran dari dua atau lebih variabel bebas terhadap satu variabel tergantung (Santoso, 2003). Uji hipotesis akan menggunakan bantuan program SPSS versi 19.0 for windows. Pada penelitian ini, peneliti menggunakan uji normalitas data melalui analisis Kolmogorov Smirnov. uji linearitas data melalui analisis compare mean, serta uji multikolinearitas data melalui nilai Variance Inflation Factor (VIF) dan nilai Collinearity Tolerance.

\section{HASIL PENELITIAN}

\section{Karakteristik Subjek}

Subjek dalam penelitian ini adalah remaja akhir di Program Studi Pendidikan Dokter Gigi Fakultas Kedokteran Universitas Udayana sejumlah 129 orang.

Tabel 1

Karakteristik Subjek Berdasarkan Jenis Kelamin

\begin{tabular}{ccc}
\hline Jenis Kelamin & Jumlah & Persentase \\
\hline Laki-laki & 36 & $27,9 \%$ \\
\hline Perempuan & 93 & $72,1 \%$ \\
\hline Total & 129 & $100 \%$ \\
\hline
\end{tabular}

Berdasarkan tabel 1, dapat diketahui bahwa subjek berjenis kelamin laki-laki dan perempuan. Mayoritas subjek berjenis kelamin perempuan dengan persentase sebesar $72,1 \%$. Tabel 2

\begin{tabular}{ccc} 
Karakteristik Subjek Berdasarkan Usia & & \\
\hline Usia & Jumlah & Persentase \\
\hline 18 tahun & 36 & $27,9 \%$ \\
\hline 19 tahun & 39 & $30,2 \%$ \\
\hline 20 tahun & 47 & $36,4 \%$ \\
\hline 21 tahun & 7 & $5,5 \%$ \\
\hline Total & 129 & $100 \%$ \\
\hline
\end{tabular}

Berdasarkan tabel 2, dapat diketahui bahwa subjek berada pada usia 18 tahun, 19 tahun, 20 tahun, dan 21 tahun. Mayoritas subjek berada pada usia 20 tahun dengan persentase sebesar $36,4 \%$.

Tabel 3

Karakteristik Subjek Berdasarkan Pendidikan Orangtua (Ayah dan Ibu)

\begin{tabular}{ccccc}
\hline \multirow{2}{*}{ Pendidikan Orangtua } & \multicolumn{2}{c}{ Ayah } & \multicolumn{2}{c}{ Ibu } \\
\cline { 2 - 5 } & Jumlah & Persentase & Jumlah & Persentase \\
\hline Pendidikan Dasar & 4 & $3,1 \%$ & 5 & $3,9 \%$ \\
\hline Pendidikan Menengah & 29 & $22,5 \%$ & 52 & $40,3 \%$ \\
\hline Pendidikan Tinggi & 96 & $74,4 \%$ & 72 & $55,8 \%$ \\
\hline Total & 129 & $100 \%$ & 129 & $100 \%$ \\
\hline
\end{tabular}




\section{PERAN POLA ASUH AUTORITATIF, EFIKASI DIRI, PERILAKU PROSOSIAL TERHADAP KESEJAHTERAAN PSIKOLOGIS PADA REMAJA AKHIR PENDIDIKAN DOKTER GIGI}

Menurut UU RI No. 20 Tahun 2003 tingkatan pendidikan dibagi menjadi tiga, yaitu pendidikan (SD dan SMP), pendidikan menengah (SMA), dan pendidikan tinggi (Diploma, S1, S2, dan S3). Karakteristik subjek berdasarkan pendidikan orangtua (ayah dan ibu) dapat dilihat pada tabel 3. Berdasarkan tabel 3, dapat diketahui bahwa subjek memiliki ayah dan ibu dengan tingkat pendidikan dasar, pendidikan menengah, dan pendidikan tinggi. Mayoritas pendidikan ayah subjek berada pada tingkat pendidikan tinggi dengan persentase sebesar $74,4 \%$, Mayoritas pendidikan ibu subjek berada pada tingkat pendidikan tinggi dengan persentase sebesar 55,8\%.

\section{Deskripsi Data Penelitian}

Tabel 4

Deskripsi Data Penelitian

\begin{tabular}{cccccccc}
\hline Variabel & $\mathrm{N}$ & $\begin{array}{c}\text { Mean } \\
\text { Teoritis }\end{array}$ & $\begin{array}{c}\text { Mean } \\
\text { Empiris }\end{array}$ & $\begin{array}{c}\text { Std Deviasi } \\
\text { Teoritis }\end{array}$ & $\begin{array}{c}\text { Std Deviasi } \\
\text { Empiris }\end{array}$ & $\begin{array}{c}\text { Sebaran } \\
\text { Teoritis }\end{array}$ & $\begin{array}{c}\text { Sebaran } \\
\text { Empiris }\end{array}$ \\
\hline KP & 129 & 87,5 & 105,98 & 17,5 & 10,180 & $35-140$ & $82-135$ \\
\hline PPA & 129 & 57,5 & 76,01 & 11,5 & 7,999 & $23-92$ & $56-92$ \\
\hline ED & 129 & 75 & 86,50 & 15 & 10,104 & $30-120$ & $57-113$ \\
\hline PP & 129 & 72,5 & 91,32 & 14,5 & 8,934 & $29-116$ & $62-115$ \\
\hline
\end{tabular}

Berdasarkan tabel 4, dapat diketahui bahwa variabel kesejahteraan psikologis memiliki mean teoritis sebesar 87,5 dan mean empiris sebesar 105,98 dengan perbedaan mean sebesar 18,48. Mean empiris lebih besar daripada mean teoritis menunjukkan bahwa subjek memiliki taraf kesejahteraan psikologis tinggi. Rentang skor subjek penelitian adalah 82 sampai dengan 135 yang berdasarkan penyebaran frekuensi, $95,35 \%$ subjek berada di atas mean teoritis.

Berdasarkan tabel 4, dapat diketahui bahwa variabel pola asuh autoritatif memiliki mean teoritis sebesar 57,5 dan mean empiris sebesar 76,01 dengan perbedaan mean sebesar 18,51. Mean empiris lebih besar daripada mean teoritis menunjukkan bahwa subjek diasuh oleh orangtua dengan taraf pola asuh autoritatif tinggi. Rentang skor subjek penelitian adalah 56 sampai dengan 92 yang berdasarkan penyebaran frekuensi, 97,67\% subjek berada di atas mean teoritis.

Berdasarkan tabel 4, dapat diketahui bahwa variabel efikasi diri memiliki mean teoritis sebesar 75 dan mean empiris sebesar 86,50 dengan perbedaan mean sebesar 11,5. Mean empiris lebih besar daripada mean teoritis menunjukkan bahwa subjek memiliki taraf efikasi diri tinggi. Rentang skor subjek penelitian adalah 57 sampai dengan 113 yang berdasarkan penyebaran frekuensi, 94,57\% subjek berada di atas mean teoritis.

Berdasarkan tabel 4, dapat diketahui bahwa variabel prososial memiliki mean teoritis sebesar 72,5 dan mean empiris sebesar 91,32 dengan perbedaan mean sebesar 18,8. Mean empiris lebih besar daripada mean teoritis menunjukkan bahwa subjek memiliki taraf perilaku prososial tinggi. Rentang skor subjek penelitian adalah 62 sampai dengan 115 yang berdasarkan penyebaran frekuensi, 99,22\% subjek berada di atas mean teoritis.

\section{Uji Asumsi}

Tabel 5

\begin{tabular}{ccc} 
Hasil Uji Normalitas & & \\
\hline Variabel & Kolmogorov Smirnov & Asymp. Sig. (2-tailed) (P) \\
\hline Kesejahteraan Psikologis & 0,588 & 0,880 \\
\hline Pola Asuh Autoritatif & 0,894 & 0,400 \\
\hline Efikasi Diri & 0,787 & 0,566 \\
\hline Perilaku Prososial & 1,195 & 0,115 \\
\hline
\end{tabular}

Berdasarkan rangkuman pada tabel 5, dapat diketahui bahwa variabel kesejahteraan psikologis menghasilkan nilai Kolmogorov Smirnov sebesar 0,588 dengan signifikansi 0,880 $(\mathrm{p}>0,05)$. Variabel pola asuh autoritatif menghasilkan nilai Kolmogorov Smirnov sebesar 0,894 dengan signifikansi 0,400 ( $>>0,05)$. Variabel efikasi diri menghasilkan nilai Kolmogorov Smirnov sebesar 0,787 dengan signifikansi 0,566 ( $p>0,05)$. Variabel perilaku prososial menghasilkan nilai Kolmogorov Smirnov sebesar 1,195 dengan signifikansi 0,115 ( $p>0,05)$. Hal ini menunjukkan data pada variabel kesejahteraan psikologis, pola asuh autoritatatif, efikasi diri, dan perilaku prososial memiliki distribusi normal.

Tabel 6

Hasil Uji Linearitas

\begin{tabular}{|c|c|c|c|c|}
\hline & & & $\mathrm{F}$ & Signifikansi \\
\hline \multirow{3}{*}{$\begin{array}{l}\text { Kesejahteraan } \\
\text { Psikologis*Pola } \\
\text { Asuh Autoritatif }\end{array}$} & \multirow{3}{*}{$\begin{array}{c}\text { Between } \\
\text { Groups }\end{array}$} & (Combined) & 1,971 & 0,006 \\
\hline & & Linearity & 32,103 & 0,000 \\
\hline & & $\begin{array}{c}\text { Deviation from } \\
\text { Linearity }\end{array}$ & 0,999 & 0,481 \\
\hline \multirow{3}{*}{$\begin{array}{c}\text { Kesejahteraan } \\
\text { Psikologis*Efikasi } \\
\text { Diri }\end{array}$} & \multirow{3}{*}{$\begin{array}{c}\text { Between } \\
\text { Groups }\end{array}$} & (Combined) & 5,466 & 0,000 \\
\hline & & Linearity & 189,503 & 0,000 \\
\hline & & $\begin{array}{c}\text { Deviation from } \\
\text { Linearity }\end{array}$ & 0,747 & 0,844 \\
\hline \multirow{3}{*}{$\begin{array}{c}\text { Kesejahteraan } \\
\text { Psikologis*Perilaku } \\
\text { Prososial }\end{array}$} & \multirow{3}{*}{$\begin{array}{c}\text { Between } \\
\text { Groups }\end{array}$} & (Combined) & 2,738 & 0,000 \\
\hline & & Linearity & 49,956 & 0,000 \\
\hline & & $\begin{array}{c}\text { Deviation from } \\
\text { Linearity }\end{array}$ & 1,164 & 0,284 \\
\hline
\end{tabular}

Berdasarkan tabel 6, dapat diketahui bahwa bahwa pada hubungan antara kesejahteraan psikologis dengan pola asuh autoritatif menghasilkan nilai signifikansi sebesar 0,000 pada Linearity $(\mathrm{p}<0,05)$ dan nilai signifikansi sebesar 0,481 pada Deviation from linearity $(p>0,05)$, sehingga menunjukkan adanya hubungan yang linear antara kesejahteraan psikologis dengan pola asuh autoritatif. Pada hubungan antara kesejahteraan psikologis dengan efikasi diri menghasilkan nilai signifikansi sebesar 0,000 pada Linearity $(\mathrm{p}<0,05)$ dan nilai signifikansi sebesar 0,844 pada Deviation from linearity $(\mathrm{p}>0,05)$, sehingga menunjukkan adanya hubungan yang linear antara kesejahteraan psikologis dengan efikasi diri. Pada hubungan antara kesejahteraan psikologis dengan perilaku prososial menghasilkan nilai signifikansi sebesar 0,000 pada Linearity $(p<0,05)$ dan nilai signifikansi sebesar 0,284 pada Deviation from linearity ( $p>0,05)$, sehingga menunjukkan adanya hubungan yang linear antara kesejahteraan psikologis dengan perilaku prososial.

Tabel 7

Hasil Uji Multikolinearitas

\begin{tabular}{ccccc}
\hline Variabel & Signikansi & \multicolumn{2}{c}{ Collinearity Statistics } & \multirow{2}{*}{ Keterangan } \\
\cline { 2 - 4 } $\begin{array}{c}\text { Pola Asuh } \\
\text { Autoritatif }\end{array}$ & 0,094 & 0,701 & 1,427 & $\begin{array}{c}\text { Tidak ada } \\
\text { multikolinearitas }\end{array}$ \\
\hline Efikasi Diri & 0,000 & 0,779 & 1,283 & $\begin{array}{c}\text { Tidak ada } \\
\text { multikolinearitas }\end{array}$ \\
\hline $\begin{array}{c}\text { Perilaku } \\
\text { Prososial }\end{array}$ & 0,006 & 0,662 & 1,511 & $\begin{array}{c}\text { Tidak ada } \\
\text { multikolinearitas }\end{array}$ \\
\hline
\end{tabular}


Berdasarkan tabel 7, dapat diketahui bahwa pada variabel pola asuh autoritatif menghasilkan nilai VIF sebesar 1,427 dan nilai Tolerance sebesar 0,701, sehingga menunjukkan tidak adanya multikolinearitas. Pada variabel efikasi diri menghasilkan nilai VIF sebesar 1,283 dan nilai Tolerance sebesar 0,779, sehingga menunjukkan tidak adanya multikolinearitas. Pada variabel perilaku prososial menghasilkan nilai VIF sebesar 1,511 dan nilai Tolerance sebesar 0,006, sehingga menunjukkan tidak adanya multikolinearitas.

\section{Uji Hipotesis}

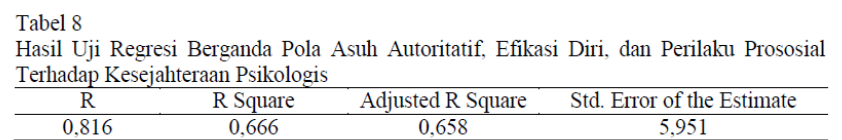

Berdasarkan tabel 8, dapat diketahui bahwa hubungan yang terjadi antara variabel bebas dan variabel tergantung pada nilai koefisien regresi (R) sebesar 0,816. Koefisien determinasi (R2) pada penelitian ini sebesar 0,666. Hal ini menunjukkan sumbangan efektif pola asuh autoritatif, efikasi diri, dan perilaku prososial secara bersama-sama terhadap kesejahteraan psikologis sebesar $66,6 \%$ dan sisanya sebesar 33,4\% dipengaruhi oleh variabel lain yang tidak diteliti pada penelitian ini.

Tabel 9

\begin{tabular}{cccccc}
\multicolumn{2}{l}{ Hasi Uji Regresi Berganda Signifikansi Nilai F } & & & \\
\hline Model & Sum of Squares & df & Mean Square & F & Sig. \\
\hline Regression & 8838,049 & 3 & 2946,016 & 83,185 & 0,000 \\
\hline Residual & 4426,881 & 125 & 35,415 & & \\
\hline Total & 13264,930 & 128 & & & \\
\hline
\end{tabular}

Berdasarkan tabel 9, dapat diketahui bahwa $\mathrm{F}$ hitung sebesar 83,185 dengan taraf signifikansi 0,000. Model regresi dapat digunakan untuk memprediksi kesejahteraan psikologis karena signifikansi berada dibawah 0,05 . Hal ini menunjukkan bahwa pola asuh autoritatif, efikasi diri, dan perilaku prososial secara bersama-sama berperan terhadap kesejahteraan psikologis.

Tabel 10

Hasil Uji Regresi Berganda Nilai Koefisien Beta dan Nilai t Variabel Pola Asuh Autoritatif, Efikasi Diri, dan Perilaku Prososial Terhadap Kesejahteraan Psikologis

\begin{tabular}{cccccc}
\hline \multirow{2}{*}{ Model } & \multicolumn{2}{c}{$\begin{array}{c}\text { Unstandardized } \\
\text { Coefficients }\end{array}$} & $\begin{array}{c}\text { Standardized } \\
\text { Coefficients }\end{array}$ & \multirow{2}{*}{ S } & Sig \\
\cline { 2 - 4 } & $\mathrm{B}$ & Std. Error & Beta & & \\
\hline (Constant) & 19,042 & 6,289 & & 3,028 & 0,003 \\
\hline PAA & 0,133 & 0,079 & 0,104 & 1,687 & 0,094 \\
\hline ED & 0,674 & 0,059 & 0,669 & 11,433 & 0,000 \\
\hline PP & 0,203 & 0,072 & 0,178 & 2,805 & 0,006 \\
\hline
\end{tabular}

Berdasarkan tabel 10, dapat diketahui bahwa pada variabel efikasi diri memiliki koefisien beta terstandarisasi sebesar 0,669 dengan nilai $t$ sebesar 11,433 dan taraf signifikansi $0,000 \quad(\mathrm{p}<0,05)$. Hal ini menunjukkan bahwa efikasi diri berperan secara signifikan terhadap kesejahteraan psikologis. Pada variabel perilaku prososial memiliki koefisien beta terstandarisasi sebesar 0,178 dengan nilai t sebesar 2,805 dan taraf signifikansi $0,006(\mathrm{p}<0,05)$. Hal ini menunjukkan bahwa perilaku prososial berperan secara signifikan terhadap kesejahteraan psikologis. Pada variabel pola asuh autoritatif memiliki koefisien beta terstandarisasi sebesar 0,104 dengan nilai t sebesar 1,687 dan taraf signifikansi 0,094 ( $p>0,05)$. Hal ini menunjukkan bahwa pola asuh autoritatif tidak berperan secara signifikan terhadap kesejahteraan psikologis.

Hasil uji regresi berganda pada tabel 10, dapat digunakan untuk memprediksi taraf kesejahteraan psikologis subjek, dengan melihat nilai konstanta, beta terstandarisasi, dan skor subjek. Prediksi taraf kesejahteraan psikologis subjek, apabila subjek memiliki taraf efikasi diri tinggi dapat dihitung dengan melakukan penambahan setiap skor subjek pada skala efikasi diri, maka taraf kesejahteraan psikologis subjek akan meningkat sebesar 0,669. Prediksi taraf kesejahteraan psikologis subjek, apabila subjek memiliki taraf perilaku prososial tinggi dapat dihitung dengan melakukan penambahan setiap skor subjek pada skala perilaku prososial, maka taraf kesejahteraan psikologis subjek akan meningkat sebesar 0,178 .

Tabel 11

Rangkuman Hasil Uji Hipotesis Penelitian

\begin{tabular}{|c|c|c|}
\hline No & Hipotesis & Hasil \\
\hline 1. & $\begin{array}{l}\text { Hipotesis Mayor } \\
\text { Pola asuh autoritatif, efikasi diri, dan perilaku prososial berperan } \\
\text { terhadap kesejahteraan psikologis pada remaja akhir di Program } \\
\text { Studi Pendidikan Dokter Gigi Fakultas Kedokteran Universitas } \\
\text { Udayana. }\end{array}$ & Diterima \\
\hline 2. & $\begin{array}{l}\text { Hipotesis Minor } \\
\text { a. Pola asuh autoritatif berperan terhadap kesejahteraan } \\
\text { psikologis pada remaja akhir di Program Studi Pendidikan } \\
\text { Dokter Gigi Fakultas Kedokteran Universitas Udayana. } \\
\text { b. Efikasi diri berperan terhadap kesejahteraan psikologis pada } \\
\text { remaja akhir di Program Studi Pendidikan Dokter Gigi } \\
\text { Fakultas Kedokteran Universitas Udayana. } \\
\text { c. Perilaku prososial berperan terhadap kesejahteraan psikologis } \\
\text { pada remaja akhir di Program Studi Pendidikan Dokter Gigi } \\
\text { Fakultas Kedokteran Universitas Udayana. }\end{array}$ & $\begin{array}{l}\text { Ditolak } \\
\text { Diterima }\end{array}$ \\
\hline
\end{tabular}

\section{PEMBAHASAN DAN KESIMPULAN}

Taraf kesejahteraan psikologis pada remaja dapat dipengaruhi oleh faktor internal dan eksternal. Faktor internal adalah faktor yang berasal dari dalam diri individu seperti efikasi diri dan perilaku prososial, sedangkan faktor eksternal adalah faktor yang berasal dari luar diri individu seperti pola asuh autoritatif yang diterapkan orangtua. Adanya variasi pada taraf kesejahteraan psikologis dapat dijelaskan melalui tinggi rendahnya efikasi diri, perilaku prosoial, dan pola asuh autoritatif yang diterapkan orangtua.

Berdasarkan hasil penelitian yang telah dilakukan dan dianalisis dengan menggunakan teknik analisa regresi berganda, dapat diketahui bahwa hipotesis mayor yaitu adanya peran pola asuh autoritatif, efikasi diri, dan perilaku prososial terhadap kesejahteraan psikologis pada remaja akhir di Program Studi Pendidikan Dokter Gigi Fakultas Kedokteran Universitas Udayana dapat diterima. Hal ini dapat dilihat dari koefisien regresi $(\mathrm{R})$ sebesar 0,816 dengan $F$ hitung sebesar $83,185$ dan taraf signifikansi 0,000 ( $\mathrm{p}<0,05)$, menunjukkan bahwa pola asuh autoritatif, efikasi diri, dan perilaku prososial secara bersama-sama berperan terhadap kesejahteraan 
psikologis. Koefisien determinasi (R2) pada penelitian ini sebesar 0,666, menunjukkan bahwa sumbangan efektif variabel bebas yaitu pola asuh autoritatif, efikasi diri, dan perilaku prososial terhadap variabel tergantung yaitu kesejahteraan psikologis sebesar 66,6\%. Hal ini menunjukkan bahwa pola asuh autoritatif, efikasi diri, dan perilaku prososial menentukan $66,6 \%$ kesejahteraan psikologis yang dimiliki remaja akhir di Program Studi Pendidikan Dokter Gigi Fakultas Kedokteran Universitas Udayana, sedangkan 33,4\% dipengaruhi oleh variabel lain yang tidak diteliti pada penelitian ini. Dari hasil koefisien beta terstandarisasi, dapat diketahui bahwa variabel bebas yang lebih berperan terhadap kesejahteraan psikologis adalah efikasi diri. Variabel efikasi diri memiliki koefisien beta terstandarisasi sebesar 0,669 dengan nilai $\mathrm{t}$ sebesar 11,433 dan taraf signifikansi 0,000 $(\mathrm{p}<0,05)$, menunjukkan bahwa efikasi diri berperan secara signifikan terhadap kesejahteraan psikologis. Variabel perilaku prososial memiliki koefisien beta terstandarisasi sebesar 0,178 dengan nilai $\mathrm{t}$ sebesar 2,805 dan taraf signifikansi 0,006 ( $<<0,05)$, menunjukkan bahwa perilaku prososial berperan secara signifikan terhadap kesejahteraan psikologis. Variabel pola asuh autoritatif memiliki koefisien beta terstandarisasi sebesar 0,104 dengan nilai t sebesar 1,687 dan taraf signifikansi 0,094 ( $>>0,05)$, menunjukkan bahwa pola asuh autoritatif tidak berperan secara signifikan terhadap kesejahteraan psikologis.

Carr (2004) yang menyatakan bahwa kesejahteraan psikologis lebih menekankan pada kondisi optimis individu yang ditandai dengan adanya keyakinan diri atas kemampuan yang dimiliki dalam mencapai kesejahteraan psikologis. Dari hasil uji regresi koefisien beta terstandarisasi dan nilai $\mathrm{t}$ menunjukkan bahwa efikasi diri berperan secara signifikan terhadap kesejahteraan psikologis pada remaja akhir. Menurut Bandura (1997) efikasi diri dapat membuat individu merasa yakin mampu mengaplikasikan kemampuan yang dimiliki, ketika berada dalam berbagai kondisi. Efikasi diri merupakan aspek mental yang penting dimiliki oleh remaja. Efikasi diri dapat membantu remaja bersikap optimis dan lebih tenang, ketika menghadapi tantangan dan hambatan dalam mencapai suatu tujuan. Remaja akan lebih cermat dalam menemukan pemecahan masalah, ketika remaja merasa mampu untuk mengorganisasi pikiran, perasaan, dan perilaku dalam menghadapi masalah. Remaja dengan keyakinan yang konsisten terhadap kemampuan diri, memiliki peluang yang besar dalam mencapai suatu keberhasilan. Pengalaman berhasil akan membuat remaja merasa percaya terhadap kemampuan diri untuk berfungsi secara optimal dalam hidup, sehingga dapat mengarahkan pada pencapaian kesejahteraan psikologis. Williams (dalam Srimathi \& Kumar, 2011) menyatakan bahwa penelitian-penelitian tentang kebahagiaan dan kesejahteraan mengidentifikasi bahwa efikasi diri merupakan komponen penting dalam pengalaman kesejahteraan individu. Efikasi diri sebagai mekanisme kognitif berperan sebagai mediator penting untuk meningkatkan kesejahteraan psikologis individu. Penelitian Flouri dan Buchanan (dalam Cripps \& Zyromski, 2009) menunjukkan bahwa efikasi diri berhubungan positif dengan konsep kebahagiaan dalam kesejahteraan psikologis. Penelitian Srimathi dan Kumar (2011) menunjukkan bahwa efikasi diri memiliki hubungan positif yang signifikan dengan setiap dimensi kesejahteraan psikologis.

Wrightsman dan Deaux (1981) menyatakan bahwa perilaku prososial didefinisikan sebagai perilaku yang memberikan konsekuensi positif secara sosial yang dapat berkontribusi dalam kesejahteraan fisik atau psikologis. Dari hasil uji regresi koefisien beta terstandarisasi dan nilai $t$ menunjukkan bahwa perilaku prososial berperan secara signifikan terhadap kesejahteraan psikologis pada remaja akhir. Remaja akhir memiliki hasrat untuk bergabung dengan orang lain atau menjadi bagian dari suatu kelompok. Menurut Eisenberg, Damon, dan Lerner (2006) perilaku prososial adalah perilaku sukarela yang memberikan keuntungan bagi orang lain untuk meningkatkan kualitas interaksi antar individu dan antar kelompok. Perilaku prososial dapat membantu remaja untuk mengembangkan kompetensi sosial yang dibutuhkan dalam menjalin hubungan yang hangat dan berkualitas dengan orang lain. Perilaku prososial akan mengarahkan remaja untuk memiliki kepedulian terhadap keadaan orang lain, memberikan perhatian dan empati terhadap orang lain, dan bersedia melakukan sesuatu untuk meringankan beban orang lain. Remaja yang melakukan perilaku prososial akan merasa bahagia, bangga, dan berharga, sehingga dapat mengarahkan pada penilaian diri yang positif. Remaja yang memiliki kompetensi sosial dan penilaian diri yang positif akan berkembang menjadi pribadi dengan kondisi mental yang sehat dan terhindar dari masalah perilaku, sehingga dapat mengarah pada pencapaian kesejahteraan psikologis. Santrock (2007a) menyatakan bahwa bentuk paling murni dari perilaku prososial adalah altruism. Altruism adalah adanya ketertarikan untuk tidak egois dalam membantu orang lain. Penelitian Verdugo, dkk, (2011) menunjukkan bahwa altruism memiliki hubungan yang positif dengan kesejahteraan psikologis pada remaja. Semakin tinggi altruism, maka semakin tinggi kesejahteraan psikologis pada remaja. Individu yang bahagia ditandai dengan adanya kemampuan bekerjasama, prososial, murah hati, dan fokus pada kebutuhan orang lain (Kasser \& Ryan, dalam Verdugo, dkk, 2011). Individu dengan emosi positif memiliki pikiran prososial dan perilaku membantu orang lain (Schroeder, dkk, dalam Verdugo, dkk, 2011). Hal ini sesuai dengan pendapat William (dalam Zainuddin dan Hidayat, 2008) yang menyatakan bahwa perilaku prososial bertujuan untuk membantu meningkatkan well-being individu. 
Santrock (2007c) menyatakan bahwa banyak orangtua yang menggunakan kombinasi dari beberapa teknik pengasuhan dan bukan menggunakan satu teknik, meskipun terdapat satu teknik yang dominan. Orangtua yang bijaksana dapat memahami pentingnya bersikap lebih permisif dalam situasi tertentu, bersikap lebih autoritarian dalam situasi lain, dan bersikap autoritatif dalam situasi lainnya. Dari hasil uji regresi koefisien beta terstandarisasi dan nilai $t$ menunjukkan bahwa pola asuh autoritatif tidak berperan secara signifikan terhadap kesejahteraan psikologis pada remaja akhir. Orangtua dengan pola asuh autoritatif akan menunjukkan kehangatan, kasih sayang, perhatian, dan empati terhadap anak, sehingga anak merasa memperoleh dukungan emosional dari orangtua. Pola asuh yang diterapkan orangtua akan memengaruhi anak dalam berpikir dan berperilaku. Santrock (2007c) menyatakan bahwa antara orangtua dan anak terdapat jurang pemisah yang sering disebut dengan kesenjangan generasi. Di masa remaja nilai-nilai dan sikap-sikap remaja menjadi semakin berbeda dengan nilai-nilai dan sikap-sikap orangtua. Kesenjangan ini dapat memicu konflik yang terjadi antara orangtua dan anak. Menurut Steinberg (dalam Keresteŝ, Brković, \& Jagodić, 2012) konflik antara orangtua dan anak dapat meningkatkan depresi pada orangtua dan menimbulkan rasa tidak mampu menjalankan peran sebagai orangtua. Konflik antara orangtua dan anak berpengaruh lebih besar terhadap kesejahteraan psikologis orangtua dibandingkan dengan kesejahteraan psikologis anak. Orangtua cenderung mengalami konflik sebagai tanda penolakan pribadi dan ketidakyakinan dalam perannya sebagai orangtua, sedangkan anak menganggap konflik sebagai kesempatan untuk melatih perkembangan kognitif dan kemampuan interpersonal.

Orangtua bukan satu-satunya pihak yang memiliki pengaruh penting terhadap remaja, karena remaja memperluas dunia sosialnya melalui hubungan yang intensif dengan teman sebaya (Santrock \& Yussen dalam Cripss \& Zyromski, 2009). Semakin bertambahnya usia, remaja akan memperoleh banyak informasi dari berbagai sumber yang berperan dalam pembentukan pengetahuan dan pengalaman remaja. Salah satu sumber informasi yang memiliki peranan penting dalam kehidupan remaja akhir adalah teman sebaya. Remaja memiliki hasrat yang besar untuk memperoleh pengalaman positif dari teman sebaya. Menurut Santrock (2007c) mayoritas individu yang berada di usia remaja akan lebih banyak menghabiskan waktu dengan teman sebaya dibandingkan dengan keluarga. Teman sebaya dapat membuat remaja mengabaikan nilai-nilai dan kendali orangtua terhadap remaja, sehingga peranan orangtua menjadi berkurang. Sullivan (dalam Cripss \& Zyromski, 2009) menyatakan bahwa kesejahteraan dibangun dari kelekatan yang stabil, hubungan pertemanan yang memuaskan, penerimaan teman sebaya, serta afeksi dan kedekatan yang intim. Penerimaan teman sebaya dapat meningkatkan self-worth. Menurut Santrock (2007c) teman sebaya berperan sebagai salah satu sumber dalam memperoleh dukungan sosial bagi remaja. Remaja memiliki kebutuhan untuk disukai dan diterima oleh teman sebaya. Remaja akan merasa senang dan nyaman apabila memperoleh penerimaan dari teman sebaya, namun akan merasa tertekan dan cemas apabila memperoleh penolakan dari teman sebaya. Penolakan dari teman sebaya berkaitan dengan masalah kesehatan mental dan masalah kenakalan remaja, sehingga dapat menurunkan taraf kesejahteraan psikologis pada remaja. Hal ini sesuai dengan pendapat Sarafino dan Smith (2010) yang menyatakan bahwa dukungan sosial diartikan sebagai kenyamanan, perhatian, ataupun bantuan yang diterima individu dari pasangan, keluarga, teman, dan organisasi masyarakat. Dukungan sosial dapat menciptakan suasana hati yang positif, yaitu perasaan tenang, aman dan dihargai sebagai bagian dari suatu kelompok sosial. Singh, Mohan, \& Anassen (2012) menyatakan bahwa dukungan sosial dan hubungan interpersonal memengaruhi kesejahteraan. Isolasi sosial, kesepian, dan kehilangan dukungan sosial berhubungan dengan peningkatan resiko penyakit atau mengurangi harapan hidup (Berkman, dkk, dalam Singh, dkk, 2012). Kehilangan dukungan sosial akan mengakibatkan kesepian, sehingga dapat memiliki efek negatif terhadap kesejahteraan psikologis (Green \& Shellenberger; Brannon \& Feist, dalam Compton, 2005).

Pada deskripsi data penelitian, variabel kesejahteraan psikologis memiliki mean teoritis sebesar 87,5 dan mean empiris sebesar 105,98, meunjukkan bahwa subjek memiliki taraf kesejahteraan psikologis tinggi (mean empiris > mean teroritis). Dari hasil kategorisasi kesejahteraan psikologis, dapat diketahui bahwa 22 orang atau 17,0\% subjek memiliki taraf kesejahteraan psikologis sedang, 78 orang atau $60,5 \%$ subjek memiliki taraf kesejahteraan psikologis tinggi, dan 29 orang atau $22,5 \%$ subjek memiliki taraf kesejahteraan psikologis sangat tinggi. Dengan demikian dapat disebutkan bahwa mayoritas taraf kesejahteraan psikologis subjek tergolong tinggi. Hal ini menunjukkan bahwa remaja akhir di Program Studi Pendidikan Dokter Gigi Fakultas Kedokteran Universitas Udayana memiliki kondisi mental yang sehat dan mampu berfungsi secara optimal dalam menjalani kehidupan. Tingginya taraf kesejahteraan psikologis yang dimiliki remaja akhir di Program Studi Pendidikan Dokter Gigi Fakultas Kedokteran Universitas Udayana dapat dikaji dari enam dimensi yaitu penerimaan diri, hubungan positif dengan orang lain, kemandirian, penguasaan lingkungan, tujuan hidup dan perkembangan pribadi. Individu dengan taraf kesejahteraan psikologis tinggi memiliki sikap yang positif terhadap diri, kemampuan dalam menjalin hubungan yang berkualitas dengan orang lain, memiliki kemandirian, adanya hasrat untuk menjadi pribadi yang selalu berkembang, serta memiliki tujuan dan makna hidup (Ryff, 1989). Penerimaan diri dipengaruhi oleh adanya penilaian diri yang positif, karena 
merasa mampu menerima kualitas positif dan negatif diri. Hubungan positif dengan orang lain dipengaruhi oleh adanya kemampuan interpersonal yang dapat dikembangkan melalui kegiatan kemahasiswaan dan organisasi kemahasiswaan di Universitas Udayana. Kemandirian dipengaruhi oleh kematangan pribadi dalam memenuhi tugas perkembangan remaja yang dapat berkembang melalui adanya sistem pembelajaran dengan memberikan penugasan kampus yang bersifat individual, sehingga remaja belajar untuk tidak tergantung pada orang lain. Penguasaan lingkungan dipengaruhi oleh adanya kemampuan dalam mengelola lingkungan agar sesuai dengan nilai dan kebutuhan pribadi yang dapat berkembang melalui kegiatan kemahasiswaan dan organisasi kemahasiswaan di Universitas Udayana. Tujuan hidup dipengaruhi oleh adanya arah dan makna dalam hidup, remaja akhir yang menjalani pendidikan di Program Studi Pendidikan Dokter Gigi Fakultas Kedokteran Universitas Udayana telah memiliki tujuan untuk berprofesi sebagai Dokter Gigi. Perkembangan pribadi dipengaruhi oleh adanya hasrat untuk terus berkembang yang dapat diasah melalui kegiatan kemahasiswaan dan organisasi kemahasiswaan di Universitas Udayana, serta mata kuliah di Program Studi Pendidikan Dokter Gigi. Pada penelitian ini belum diperoleh data empiris tentang sistem pembelajaran, kegiatan kemahasiswaan, dan organisasi kemahasiswaan, sehingga diperlukan penelitian lebih lanjut mengenai keterkaitan antara sistem pembelajaran, kegiatan kemahasiswaan, dan organisasi kemahasiswaan dengan kesejahteraan psikologis.

Pada deskripsi data penelitian, variabel pola asuh autoritatif memiliki mean teoritis sebesar 57,5 dan mean empiris sebesar 76,01, menunjukkan bahwa subjek diasuh dengan taraf pola asuh autoritatif tinggi (mean empiris > mean teroritis). Dari hasil kategorisasi pola asuh autoritatif, dapat diketahui bahwa 8 orang atau 6,2\% subjek diasuh dengan taraf pola asuh autoritatif sedang, 49 orang atau 38,0\% subjek diasuh dengan taraf pola asuh autoritatif tinggi, dan 72 orang atau 55,8\% subjek diasuh dengan taraf pola asuh autoritatif sangat tinggi. Dengan demikian dapat disebutkan bahwa mayoritas subjek diasuh dengan taraf pola asuh autoritatif tergolong sangat tinggi. Hal ini menunjukkan bahwa remaja akhir di Program Studi Pendidikan Dokter Gigi Fakultas Kedokteran Universitas Udayana berkembang di keluarga yang memiliki keseimbangan antara responsiveness dan demaningness, sehingga akan mengarahkan anak untuk memiliki penilaian diri yang objektif, memiliki kompetensi sosial yang lebih baik, dan tidak terlibat dalam masalah perilaku baik pada anak laki-laki ataupun perempuan dalam setiap tahapan perkembangan.

Penerapan pola asuh autoritatif yang tinggi pada remaja akhir di Program Studi Pendidikan Dokter Gigi Fakultas Kedokteran Universitas Udayana dapat dikaji dari pendidikan orangtua yang dikategorikan berpendidikan tinggi.
Olson dan DeFrain (2003) menyatakan bahwa pendidikan orangtua akan memengaruhi cara orangtua dalam melakukan komunikasi, menerapan disiplin, dan penanaman nilai-nilai kepada anak. Latar belakang pendidikan orangtua dapat memengaruhi pola pikir yang menentukan harapan dan perlakuan orangtua terhadap anak. Orangtua dengan tingkat pendidikan yang tinggi akan lebih sering membaca referensi atau mengikuti kemajuan pengetahuan tentang perkembangan anak, sehingga akan lebih siap dan memiliki pemahaman yang luas dalam penerapan pengasuhan yang efektif terhadap anak. Orangtua yang menyadari pentingnya pemberian kasih sayang dan penerapan disipin pada pengasuhan anak, cenderung menerapkan pola asuh autoritatif. Santrock (2007c) yang menyatakan bahwa pola asuh autoritatif dianggap sebagai pola asuh yang paling efektif. Orangtua dengan pola asuh autoritatif menunjukkan kehangatan, dukungan otonomi, dan komunikasi dua arah, namun tetap melakukan kontrol dan mengawasi aktivitas anak. Hal ini sesuai dengan penelitian Farida dan Naviati (2014) yang menunjukkan bahwa orangtua dengan tingkat pendidikan tinggi cenderung menerapkan pola asuh autoritatif. Penelitian Kharmina (2011) menunjukkan bahwa adanya pengaruh positif yang signifikan antara tingkat pendidikan orangtua dengan pola asuh yang diterapkan orangtua. Semakin tinggi tingkat pendidikan orangtua, maka semakin baik pola asuh yang diterapkan orangtua. Orangtua yang berpendidikan tinggi akan memilih pola asuh yang berdampak positif terhadap anak, yang ditandai dengan adanya kontrol terhadap anak, komunikasi dua arah, penerapan disiplin, dan pemberian hukuman yang sesuai dengan tingkat kesalahan anak. Perlakuan orangtua yang demikian cenderung mendekati pola asuh autoritiatif. Pada penelitian ini belum dilakukan uji beda terhadap data pendidikan orangtua, sehingga belum diperoleh data empiris yang pasti mengenai variasi pola asuh autoritatif berdasarkan tingkat pendidikan orangtua. Uji beda variasi pola asuh autoritatif berdasarkan pendidikan orangtua dapat dijadikan penelitian lanjutan.

Pada deskripsi data penelitian, variabel efikasi diri memiliki mean teoritis sebesar 75 dan mean empiris sebesar 86,50, menunjukkan bahwa subjek memiliki taraf efikasi diri tinggi (mean empiris > mean teroritis). Dari hasil kategorisasi efikasi diri, dapat diketahui bahwa 4 orang atau 3,1\% subjek memiliki taraf efikasi diri rendah, 40 orang atau 31,0\% subjek memiliki taraf efikasi diri sedang, 71 orang atau 55,0\% subjek memiliki taraf efikasi diri tinggi, dan 14 orang atau $10,9 \%$ subjek memiliki taraf efikasi diri sangat tinggi. Dengan demikian dapat disebutkan bahwa mayoritas taraf efikasi diri subjek tergolong tinggi. Hal ini menunjukkan bahwa remaja akhir di Program Studi Pendidikan Dokter Gigi Fakultas Kedokteran Universitas Udayana memiliki kepercayaan diri, keyakinan pada kemampuan diri, gigih dalam mencapai 
tujuan, terbuka terhadap pengalaman baru, dan tidak mudah menyerah dalam menghadapi tantangan atau hambatan.

Tingginya taraf efikasi diri yang dimiliki remaja akhir di Program Studi Pendidikan Dokter Gigi Fakultas Kedokteran Universitas Udayana dapat dikaji dari adanya pengalaman berhasil yang dicapai, ketika mampu diterima dan menjalani pendidikan di salah satu fakultas terfavorit di Universitas Udayana. Pengalaman berhasil mampu meningkatkan kepercayaan akan kemampuan diri, sehingga akan memiliki keyakinan dalam mencapai kesuksesan yang serupa dimasa mendatang. Hal ini sesuai dengan pendapat Bandura (1997) yang menyatakan bahwa pengalaman berhasil merupakan sumber yang paling memengaruhi efikasi diri, karena dapat memberi bukti yang nyata atas kemampuan dalam mencapai kesuksesan. Semakin sering individu berhasil dalam mengerjakan suatu tugas atau tantangan, maka efikasi diri yang ada akan semakin meningkat. Pada penelitian ini belum diperoleh data empiris tentang pengalaman berhasil berupa pencapaian prestasi akademis maupun non akademis, sehingga diperlukan penelitian lebih lanjut mengenai keterkaitan antara pencapaian prestasi dengan efikasi diri.

Pada deskripsi data penelitian, variabel perilaku prososial memiliki mean teoritis sebesar 72,5 dan mean empiris sebesar 91,32, menunjukkan bahwa subjek memiliki taraf perilaku prososial tinggi (mean empiris > mean teroritis). Dari hasil kategorisasi perilaku prososial, dapat diketahui bahwa 1 orang atau $0,8 \%$ subjek memiliki taraf perilaku prososial rendah, 1 orang atau $0,8 \%$ subjek memiliki taraf perilaku prososial sedang, 90 orang atau 69,7\% subjek memiliki taraf perilaku prososial tinggi, dan 37 orang atau $28,7 \%$ subjek memiliki taraf perilaku prososial sangat tinggi. Dengan demikian dapat disebutkan bahwa mayoritas taraf perilaku prososial subjek tergolong tinggi. Hal ini menunjukkan bahwa remaja akhir di Program Studi Pendidikan Dokter Gigi Fakultas Kedokteran Universitas Udayana memiliki hasrat untuk melakukan tindakan yang dapat memberikan manfaat dan keuntungan secara sosial terhadap orang lain.

Tingginya taraf perilaku prososial yang dimiliki remaja akhir di Program Studi Pendidikan Dokter Gigi Fakultas Kedokteran Universitas Udayana dapat dikaji dari adanya organisasi kemahasiswaan dan kegiatan kemahasiswaan. Keterlibatan dalam organisasi memberikan kesempatan remaja untuk belajar dalam menjalin relasi dengan orang lain. Penelitian yang dilakukakan oleh Baihaqqi (2007) menunjukkan bahwa keterlibatan individu dalam suatu organisasi memiliki peran yang penting dalam kemampuan bekerjasama dan menolong, sehingga dapat meningkatkan intensi perilaku prososial. Kegiatan kemahasiswaan berupa pengabdian masyarakat dan bakti sosial merupakan aktivitas sosial yang rutin dilakukan oleh subjek. Kegiatan sosial memberikan pengalaman belajar mengenai fenomena yang ada di lingkungan sosial, sehingga remaja mampu mengaplikasikan pengetahuan yang dimiliki dan mengembangkan kemampuan interpersonal melalui empati dan kepedulian terhadap orang lain. Hal ini sesuai dengan pendapat Rahman (2013) yang menyatakan bahwa faktor situasional berpengaruh terhadap kemunculan perilaku menolong. Perilaku prososial dapat berkembang melalu proses belajar sosial dengan cara mengamati dan meniru perilaku orang sekitarnya. Keterlibatan dalam kegiatan sosial mampu membuat remaja menjadi termotivasi dalam melakukan perilaku prososial melalui kesediaan bekerjasama untuk mencapai tujuan, memberikan pertolongan untuk meringankan beban orang lain, berbagi dengan orang lain yang membutuhkan, dan memberikan bantuan secara sukarela. Pada penelitian ini belum diperoleh data empiris tentang organisasi kemahasiswaan dan kegiatan kemahasiswaan, sehingga diperlukan penelitian lebih lanjut mengenai keterkaitan antara organisasi kemahasiswaan dan kegiatan kemahasiswaan dengan perilaku prososial.

Berdasarkan penelitian dan analisis data yang telah dilakukan, maka dapat disimpulkan bahwa Pola asuh autoritatif, efikasi diri, dan perilaku prososial secara bersamasama berperan terhadap kesejahteraan psikologis pada remaja akhir di Program Studi Pendidikan Dokter Gigi Fakultas Kedokteran Universitas Udayana. Secara parsial, pola asuh autoritatif tidak berperan secara signifikan terhadap kesejahteraan psikologis pada remaja akhir di Program Studi Pendidikan Dokter Gigi Fakultas Kedokteran Universitas Udayana. Efikasi diri berperan terhadap kesejahteraan psikologis pada remaja akhir di Program Studi Pendidikan Dokter Gigi Fakultas Kedokteran Universitas Udayana. Perilaku prososial berperan terhadap kesejahteraan psikologis pada remaja akhir di Program Studi Pendidikan Dokter Gigi Fakultas Kedokteran Universitas Udayana. Kesejahteraan psikologis pada remaja akhir di Program Studi Pendidikan Dokter Gigi Fakultas Kedokteran Universitas Udayana tergolong tinggi, karena mayoritas subjek subjek memiliki kesejahteraan psikologis yang tinggi dengan persentase sebesar $60,5 \%$. Pola asuh autoritatif yang diterapkan orangtua pada remaja akhir di Program Studi Pendidikan Dokter Gigi Fakultas Kedokteran Universitas Udayana tergolong sangat tinggi, karena mayoritas subjek diasuh dengan pola asuh autoritatif yang sangat tinggi dengan persentase sebesar $55,8 \%$. Efikasi diri pada remaja akhir di Program Studi Pendidikan Dokter Gigi Fakultas Kedokteran Universitas Udayana tergolong tinggi, karena mayoritas subjek memiliki efikasi diri yang tinggi dengan persentase sebesar 55,0\%. Perilaku prososial pada remaja akhir di Program Studi Pendidikan Dokter Gigi Fakultas Kedokteran Universitas Udayana tergolong tinggi, karena mayoritas subjek memiliki perilaku prososial yang tinggi dengan persentase sebesar $69,7 \%$. 


\section{PERAN POLA ASUH AUTORITATIF, EFIKASI DIRI, PERILAKU PROSOSIAL TERHADAP KESEJAHTERAAN PSIKOLOGIS PADA REMAJA AKHIR PENDIDIKAN DOKTER GIGI}

Saran bagi orangtua, orangtua diharapkan mampu mengembangkan pola asuh yang dapat membantu anak mengembangkan efikasi diri dan perilaku prososial sejak diri, sehingga dapat terinternalisasi dengan baik di usia remaja. Orangtua diharapkan mampu memberikan perlakuan yang dapat meningkatkan efikasi diri anak. Hal ini dapat terwujud dengan cara menyediakan tantangan kepada anak dalam setiap kegiatan, menciptakan suasana yang positif bagi anak, dan mengembangkan komunikasi dua arah dengan anak, sehingga anak memperoleh pengalaman berhasil, memiliki suasana hati yang positif, dan memperoleh persuasi verbal yang akan membantu proses perkembangan efikasi diri. Orangtua diharapkan mampu memberikan perlakuan yang dapat meningkatkan perilaku prososial anak. Hal ini dapat terwujud dengan cara memberikan kesempatan pada anak untuk terlibat dalam kegiatan sosial, sehingga anak akan belajar mengembangkan perilaku prososial.

Saran bagi remaja akhir, remaja diharapkan mampu meningkatkan efikasi diri yang dapat berperan dalam pencapaian kesejahteraan psikologis. Hal ini dapat terwujud dengan cara bersikap terbuka terhadap pengalaman baru, mengembangkan potensi diri, gigih dan tekun dalam proses pencapaian, sehingga remaja memiliki pengalaman berhasil yang akan membantu proses perkembangan efikasi diri. Remaja diharapkan mampu meningkatkan perilaku prososial yang dapat berperan dalam pencapaian kesejahteraan psikologis. Hal ini dapat terwujud dengan cara mengembangkan hubungan interpersonal yang hangat dan terlibat dalam kegiatan sosial, sehingga remaja akan memperoleh pengalaman belajar di lingkungan sosial.

Saran bagi institusi pendidikan, institusi pendidikan diharapkan mampu merancang program pembelajaran untuk meningkatkan efikasi diri yang dapat berperan dalam pencapaian kesejahteraan psikologis. Hal ini dapat terwujud melalui kegiatan pelatihan, seminar, dan perlombaan yang menyediakan kesempatan mahasiswa untuk mengembangkan potensi diri dan mencapai prestasi yang akan membantu proses perkembangan efikasi diri. Institusi pendidikan diharapkan mampu merancang program pembelajaran untuk meningkatkan perilaku prososial yang dapat berperan dalam pencapaian kesejahteraan psikologis. Hal ini dapat terwujud melalui kegiatan sosial yang memberikan kesempatan mahasiswa untuk mengembangkan hubungan interpersonal yang hangat dan kepedulian terhadap orang lain, sehingga remaja akan memperoleh pengalaman belajar di lingkungan sosial.

Saran bagi peneliti selanjutnya, peneliti selanjutnya diharapkan mampu menggunakan sampel yang lebih besar, agar data yang diperoleh dapat lebih representatif dan bervariasi. Peneliti selanjutnya diharapkan mampu melakukan penelitian mengenai keterkaitan antara teman sebaya dengan kesejahteraan psikologis remaja, karena teman sebaya memiliki peran yang penting bagi kehidupan remaja. Pada penelitian ini belum diperoleh data empiris tentang sistem pembelajaran, kegiatan kemahasiswaan, dan organisasi kemahasiswaan, sehingga peneliti selanjutnya diharapkan mampu melakukan penelitian mengenai keterkaitan antara sistem pembelajaran, kegiatan kemahasiswaan, dan organisasi kemahasiswaan dengan kesejahteraan psikologis. Pada penelitian ini belum dilakukan uji beda terhadap data pendidikan orangtua, sehingga belum diperoleh data empiris yang pasti mengenai variasi pola asuh berdasarkan tingkat pendidikan orangtua. Peneliti selanjutnya diharapkan mampu melakukan penelitian mengenai keterkaitan antara tingkat pendidikan orangtua dengan pola asuh yang diterapkan orangtua. Pada penelitian ini belum diperoleh data empiris tentang prestasi akademis dan non akademis, sehingga peneliti selanjutnya diharapkan mampu melakukan penelitian mengenai keterkaitan antara pencapaian prestasi dengan efikasi diri. Pada penelitian ini belum diperoleh data empiris tentang organisasi kemahasiswaan dan kegiatan kemahasiswaan, sehingga peneliti selanjutnya diharapkan mampu melakukan penelitian mengenai keterkaitan antara organisasi kemahasiswaan dan kegiatan kemahasiswaan dengan perilaku prososial. Peneliti selanjutnya diharapkan mampu melakukan studi pendahuluan terhadap populasi penelitian, sehingga memperoleh informasi tentang karakteristik dan fenomena yang terjadi pada populasi.

\section{DAFTAR PUSTAKA}

Alzahem, A.M., Molen, H.T.V.D., Alaujan, A.H, Schmidt, H.G., \& Zamakhshary, M.H. (2011). Stress Amongst Dental Students: A Systematic Review. European Journal of Dental Education. 15, 8-18.

Archana, Kumar, U. \& Singh, R. (2014). Resilience and Spirituality as Predictors of Psychological Well-being among Univercsity Students. Journal of Psychosocial Research. 9(02), 227-235.

Bandura, A. (1997). Self Efficacy The Exercise of Control. New York: W.H Freeman and Company.

Baihaqqi, A. (2007). Perilaku Prososial Mahasiswa UIN Syarif Hidayarullah Jakarta. Skripsi (Tidak Diterbitkan). Fakultas Psikologis Universitas Islam Negeri, Jakarta.

Baumrind, D. (1966). Effects of Authoritative Parental Control on Child Behavior. Child Development. 37(4), 887-907.

Baumrind, D. (2005). Patterns of Parental Authority and Adolescent Autonomy. New Directions for Child and Adolescent Development. Summer. (108), 61-69.

Carr, A. (2004). Positive Psychology: The Science of Happiness and Human Strengths. New York: Brunner-Routledge.

Compton, W.C. (2005). An Introduction to Positive Psychology. United State: Thomson Wadsworth.

Cripps, K. \& Zyromski, B. (2009). Adolescents' Psychological Wellbeing and Perceived Parental Involvemen: Implications for Parental Involvement in Middle Schools. RMLE Online. 33(04), 1-13. 
Eisenberg, N., Damon, W., \& Lerner, R.M. (2006). Handbook of Child Psychology. United state: John Wiley \& Sons. Inc.

Eisenberg, N. \& Mussen, P.H. (1989). The Roots of Prosocial Behavior In Children. New York: Cambridge University Press.

Farida, L.N. \& Naviati, E. (2014). Hubungan Pola Asuh Otoritatif dengan Perkembangan Mental Emosional pada Anak Usia Prasekolah di TK Melati Putih Bayumanik. Prosiding Seminar Nasional. 2(02), 222-228.

Feist, J. \& Feist, G.J. (2013). Teori Kepribadian. Edisi Tujuh. Jakarta: Salemba Humanika.

Hasan, A. (2013, 31 Mei). Gelar Pesta Narkoba, 18 Remaja Bogor Dibekuk. Liputan6.com. http://news.liputan6.com/read/601489/gelar-pesta-narkoba18-remaja-bogor-dibekuk. Diakses pada 30 September 2015.

Hurlock, E.B. (1980). Psikologi Perkembangan Suatu Pendekatan Sepanjang Rentang Kehidupan. Edisi Kelima. Jakarta: Erlangga.

Keresteŝ, G., Brković, I., \& Jagodić, G.K. (2012). Predictors of Psychological Well-being of Adolescencts' Parents. J Happiness Stud. 13, 1073-1089.

Kharmina, N. (2011). Hubungan antara Tingkat Pendidikan Orangtua dengan Orientasi Anak Usia Dini. Skripsi (Tidak Diterbitkan). Fakultas Ilmu Pendidikan Universitas Negeri Semarang, Semarang.

Liputan 6. (2011, 25 Juli). Putri Aryanti Kenal Narkoba Sejak Remaja. Liputan6.com. http://news.liputan6.com/read/345757/putri-aryanti-kenalnarkoba-sejak-remaja. Diakses pada 30 September 2015.

Liputan 6. (2015, 7 Juni). Sosok Minggu Ini: Agus, Remaja Penggerak Sekolah Rakyat. Liputan6.com. http://tv.liputan6.com/read/2247008/sosok-minggu-iniagus-remaja-penggerak-sekolah-rakyat. Diakses pada 30 September 2015.

Maynard, M.J. \& Harding, S. (2010). Ethnic Differences in Psychological Well-being in Adolescence in the Context of Time Spent in Family Activities. Soc Psychiat Epidemol. 45, (115-123).

Olson, D.H. \& DeFrain, J. (2003). Marriages and Families. Boston: Mc. Graw Hill.

Polimpung, J.A.F. (2012). Pengaruh Stres, Depresi, dan Kecemasan Terhadap Volume Saliva Pada Mahasiswa Preklinik Fakultas Kedokteran Gigi Universitas Hasanuddin. Skripsi (Tidak Diterbitkan). Fakultas Kedokteran Gigi, Makasar.

Polychronopoulou, A. \& Divaris, K. (2009). Dental Students' Perceived Sources of Stress: A Multi-Country Study. Journal of Dental Education. 73(05), 631-629.

Qodar, N. (2015, 11 Januari). Christy, Remaja Pemprakarsa Kursus Bahasa Inggris Gratis. Liputan6.com. http://news.liputan6.com/read/2159310/christy-remajapemprakarsa-kursus-bahasa-inggris-gratis. Diakses pada 30 September 2015.

Rahman, A.A. (2013). Psikologi Sosial: Integrasi Pengetahuan Wahyu dan Pengetahuan Empirik. Jakarta: Raja Grafindo Persada.
Rustika, I.M. (2014). Faktor-Faktor yang Memengaruhi Prestasi Akademik pada Remaja. Disertasi (tidak diterbitkan). Fakultas Psikologi Universitas Gadjah Mada, Yogyakarta.

Ryff, C.D. (1989). Happiness is Everything, or is it ? Explorations on the Meaning of Psychological Well-being. Journal of Personality and Social Psychology. 59(06), 1069-1081.

Ryff, C.D. \& Keyes, C.L. (1995). The Structure of Psycological Well-being Revised. Journal of Personality and Social Psychology. 69(04), 719-727.

Ryff, C.D. (2014). Psychological Well-being Revisited: Advances in the Science and Practice of Eudaimonia. Psychotherapy and Psychosomatics. 83, 10-28.

Santoso, S. (2003). Mengatasi Berbagai Masalah Statistik dengan SPSS versi 11.5. Jakarta: PT. Gramedia.

Santrock, J.W. (2007a). Perkembangan Anak. Jilid 2. Jakarta: Erlangga.

Santrock, J.W. (2007b). Remaja. Jilid 1. Jakarta: Erlangga.

Santrock, J.W. (2007c). Remaja. Jilid 2. Jakarta: Erlangga.

Sarafino, E.P. \& Smith, T.M. (2010). Health Psychology Biopsychosocial Interaction. New York: John Wiley \& Sons, Inc.

Sarwono, S.W. (2013). Psikologi Remaja. Jakarta: Rajawali Pers.

Singh, K., Mohan, J., \& Anassen, M. (2012). Psychological Wellbeing: Dimensions, Measurements, and Applications. Germany: Lambert Academic Publishing.

Srimathi, N.L. \& Kumar, S.K.K. (2011). Self Efficacy and Psychological Well-being among Employed Women. J. Psychosoc. Rec. 6(01). 95-102.

Sugiyono. (2012). Statistik untuk Penelitian. Bandung: Alfabeta.

Sugiyono. (2014). Metode Penelitian Kombinasi: Mixed Methods. Bandung: Alfabeta.

Undang-Undang Republik Indonesia Nomor 20 Tahun 2003 tentang Sistem Pendidikan Nasional.

Verdugo, V.C., Carbajal, M.M.M., Petterson, M.S., Armenta, M.F., Fonllem, C.T., \& Sing, B.F. (2011). International Journal of Hispanic Psychology. 4(01), 31-44.

Wrightsman, L.S. \& Deaux, K. (1981). Social Psychology in The 80'S. Third Edition. Unated State: Wadsworth, Inc.

Zainuddin, Z. \& Hidayat, R. (2008). Hubungan Intensi Pro-Sosial Pustakawan dengan Kepuasan Pengguna pada Badan Perpustakaan dan Arsip Daerah (Baperasda) Provinsi Sumatera Utara. Pustaha: Jurnal Studi Perpustakaan dan Informasi. 4(02), 45-59. 